Febriani Sarwendah Asri Nugraheni, Jailani, Sri Purwati. (2019). Pengaruh Pasta Tomat Terhadap Kolesterol Darah Mencit. Journal Bioeksperimen. Vol. 5 (2) Pp. 136-139. Doi: 10.23917/bioeksperimen.v5i2.2795

\title{
PENGARUH PASTA TOMAT TERHADAP KOLESTEROL DARAH MENCIT
}

\author{
Febriani Sarwendah Asri Nugraheni ${ }^{1 *}$, Jailani ${ }^{2}$, Sri Purwati ${ }^{2}$ \\ ${ }^{1}$ Pascasarjana Universitas Negeri Malang \\ ${ }^{2}$ Prodi Pendidikan Biologi Universitas Mulawarman \\ *E-mail: fasrinugraheni@ymail.com
}

Paper diterima : 24 November 2018, Paper publish : September 2019

\begin{abstract}
This study aims to determine the effect of tomato paste on blood cholesterol in mice. It was an experimental study using a complete randomized study design consisting of four treatments P0, P1, P2, and P3 by giving tomato paste solution in a concentration of $0 \%, 20 \%, 40 \%$ and $80 \%$ and 6 replications. Data were analyzed using Anova one path and continued with BNT with a confidence level of $95 \%$. The results showed that the tomato paste solution affected the blood cholesterol of mice due to Fhit (3.27)> F tab (3.10) and the treatment that gave the greatest effect was on giving the concentration of tomato paste solution by $80 \%$.
\end{abstract}

Keywords: Tomato Pasta, mice, blood, cholesterol

\section{Pendahuluan}

Aktivitas manusia yang semakin tinggi berpengaruh terhadap pola hidup, karena semakin sibuk manusia dengan kehidupan sehari-hari tuntutan untuk hidup serba cepat juga meningkat. Tuntutan untuk hidup serba cepat ini berpengaruh terhadap gaya hidup seseorang, misalnya berkurangnya olahraga, merokok dan meningkatnya konsumsi makanan cepat saji karena dianggap praktis padahal gaya hidup tersebut meningkatkan resiko terjadinya penyakit degeneratif seperti dibetes mellitus (Inzucchi et al., 2005; Betteng dkk, 2014; Jelantik \& Erna, 2014) dan kolesterol tinggi (hypercholesterolemia) (LIPI, 2009; Bantas dkk, 2012). Dari data sistem rumah sakit pada tahun 2010-2011 diketahui penyakit jantung, stroke dan hipertensi lebih banyak diderita masyarakat daripada penyakit degeneratif lain dan di rumah sakit, pasien penyakit jantung merupakan pasien prioritas untuk ditangani (Kemenkes RI, 2012). Penyebab penyakit jantung, stroke dan hipertensi antara lain kolesterol. Pengobatan yang biasa dilakukan adalah menggunakan obat anti kolesterol buatan padahal obat ini memiliki efek samping bagi kesehatan seperti takikardi, peningakatan enzim hati, miopati, gangguan saluran cerna, sakit kepala (Stancu \& Anca, 2001; Williams, 2005, Sullivian, 2007), rhabdomylosis, dan mempengaruhi sistem saraf pusat (Sullivan, 2007).

Berbahayanya resiko dari kolesterol dan pengobatan dengan menggunakan bahan sitetis tersebut maka sebaiknya dicari solusi untuk menghindarinya dengan mengubah pola hidup menjadi lebih sehat misalnya dengan menghindari rokok, berolahraga dan menjaga asupan makan yang seimbang misalnya makanan yang mengandung serat dan antioksidan seperti buah-buahan dan sayur. Salah satu buah yang mengandung antioksidan tinggi yang banyak dikonsumsi masyarakat adalah tomat. Tomat memiliki kandungan lycopene yang melimpah dan memiliki aktivitas antioksidan untuk menghindari peroksidasi lipid karena memiliki aktivitas antioksidan yang lebih kuat dari $\beta$-caroten dan $\alpha$-tokoferol (Jenkins \& Mackinney, 1951; Mascio et al., 1989; Miller et al., 1996; Kelkel et al., 2011). Kandungan 
likopen dalam tomat dipengaruhi oleh varietas, tingkat kematangan , lama penyimpanan, dan pemanasan (Thompson et al., 2000). Tomat yang telah mengalami proses pengolahan akan meningkat bio-availabilitynyadibandingkan dengan tomat segar (Shi \& Maguer, 2000; Alda et al., 2009; Nasir et al., 2015).

Penelitian ini bertujuan untuk mengetahui pengaruh pasta tomat terhadap kolesterol darah mencit.

\section{Metode Penelitian}

Penelitian ini adalah penelitian eksperimental dengan menggunakan rancangan acak lengkap.

\section{Alat dan Bahan}

Percobaan dilakukan dengan menggunakan 4 perlakuan dan 6 ulangan kepada subjek coba berupa mencit jantan Balb $\mathrm{C}$ yang berusia tiga bulan. Mencit diaklimatisasi selama 14 hari dengan diberi pakan standar untuk menyeragamkan kondisi awal mencit. Setelah aklimatisasi, mencit kemudian diinduksi hypercholesterolemia dengan diberikan diet kuning telur yang dicampur dengan larutan gula $90 \%$ sebanyak $1 \mathrm{ml}$ perhari selama 7 hari dan diukur kolesterol totalnya pada hari ke-8. Pasta tomat dibuat dengan cara memblansir tomat masak yang masih keras pada suhu $80^{\circ} \mathrm{C}$ selama 15 menit kemudian dihancurkan dan disaring. Pure tomat tersebut dikurangi kadar airnya dengan menggunakan evaporator. Penentuan dosis pemberian larutan pasta tomat dengan menggunakan rumus:

$$
\begin{aligned}
\mathrm{L} & =\mathrm{M} \times \mathrm{FK} \\
& =14,2 \mathrm{~g} \times 0,0026 \\
& =0,04 \mathrm{~g}
\end{aligned}
$$

Keterangan:

$\mathrm{M}=$ Kebutuhan likopen manusia perhari FK $=$ Faktor Konversi Mencit

Selanjutnya dilakukan pengenceran untuk mengetahui dosis normal yang dibutuhkan dengan menggunakan rumus:

$$
\mathrm{x}=4 \mathrm{~g}
$$

Dosis yang ditentukan diberikan kepada mencit adalah 5 kali lipat dosis normal $(20 \mathrm{~g}$ per $100 \mathrm{ml}$ air), 10 kali lipat dari dosis normal (40 g per $100 \mathrm{ml}$ air), dan 20 kali lipat dari dosis normal (80 g per $100 \mathrm{ml}$ air). Larutan pasta tomat ini diberikan sebanyak $1 \mathrm{ml}$ perhari dan diberikan pada hari ke -9 sampai ke-15. Kolesterol total mencit diukur pada hari ke-16. Analisis data dilakukan dengan menggunakan uji normalitas data Liliefors, uji homogenitas data Barlett, Anova dan dilanjutkan dengan BNT.

\section{Hasil dan Pembahasan}

Berdasarkan hasil penelitian diperoleh bahwa pemberian diet kuning telur dan larutan gula memberikan efek menaikkan rata-rata kolesterol darah mencit dari 95,2 mg/dl menjadi menjadi $151,7 \mathrm{mg} / \mathrm{dl}$ (tabel 1) sedangkan setelah pemberian pasta tomat, rata-rata kolesterol darah pada mencit mengalami perubahan menjadi 141,6 mg/dl (Tabel 2).

Tabel 1. Kolesterol Darah Mencit setelah Diet dengan Kuning Telur dan Larutan Gula

\begin{tabular}{cc}
\hline Perlakuan & Rata-Rata Kolesterol Darah (mg/dl) \\
\hline $\mathrm{P}_{0}$ & 148,8 \\
$\mathrm{P}_{1}$ & 146,5 \\
$\mathrm{P}_{2}$ & 152,8 \\
$\mathrm{P}_{3}$ & 158,5 \\
Total & 606,5 \\
\hline Rata-rata & 151,7 \\
\hline
\end{tabular}

Sumber: Hasil Penelitian (2015)

Tabel 2. Kolesterol Darah Mencit setelah Pemberian Pasta Tomat

\begin{tabular}{cc}
\hline Perlakuan & Rata-Rata Kolesterol Darah $(\mathbf{m g} / \mathbf{d l})$ \\
\hline $\mathrm{P}_{0}$ & 160,6 \\
$\mathrm{P}_{1}$ & 145,8 \\
$\mathrm{P}_{2}$ & 138,6 \\
$\mathrm{P}_{3}$ & 121,3 \\
Total & 566,3 \\
\hline Rata-Rata & 141,6 \\
\hline \multicolumn{2}{c}{ Sumber: Hasil Penelitian (2015) }
\end{tabular}

Sumber: Hasil Penelitian (2015) 
Tabel 3. Hasil Anova Kolesterol Darah Mencit setelah

\begin{tabular}{|c|c|c|c|c|c|}
\hline \multicolumn{6}{|c|}{ Pemberian Pasta Tomat } \\
\hline $\begin{array}{l}\text { Sumber } \\
\text { Variansi }\end{array}$ & dB & $\begin{array}{l}\text { Jumlah } \\
\text { Kuadrat }\end{array}$ & $\begin{array}{c}\text { Kuadrat } \\
\text { TTTTeTengah }\end{array}$ & $\mathbf{F}_{\text {hit }}$ & $\mathbf{F}_{\text {tab }}$ \\
\hline Perlakuan & 3 & 4804.792 & 1601.597 & & \\
\hline Galat & 20 & 9772.833 & 488.6417 & 3.27 & 3.10 \\
\hline Total & 23 & 14577.63 & & & \\
\hline
\end{tabular}

Hasil uji normalitas dan homogenitas diketahui bahwa data berdistribusi normal dan homogen. Berdasarkan hasil perhitungan Anova diketahui bahwa terdapat pengaruh pasta tomat terhadap kolesterol darah mencit karena $\mathrm{F}_{\text {hitung }}(3,27)>\mathrm{F}_{\text {tabel }}(3,10)$ (tabel 3) dan hasil perhitungan $\mathrm{BNT}$ diketahui bahwa $\mathrm{P}_{1}$ dan $\mathrm{P}_{2}$ berbeda tidak signifikan dengan $\mathrm{P}_{0}$ sedangkan $\mathrm{P}_{3}$ berbeda signifikan dengan $\mathrm{P}_{0}$. Hal ini menunjukkan bahwa konsentrasi larutan pasta tomat yang terbaik untuk menurunkan kolesterol darah mencit adalah $\mathrm{P}_{3}$.

Kolesterol darah pada mencit yang diberikan larutan pasta tomat kemungkinan mengalami penurunan karena adanya likopen pada tomat yang telah diolah. Tomat yang dijadikan pasta merupakan tomat yang sudah masak dengan kandungan lykopene sekitar 12,34-12,58 $\mathrm{mg} / 100 \mathrm{~g}$ sedangkan pada saat sudah diolah menjadi pasta kadar lycopene 15,65-15,83 (Alda et al., 2009). Kandungan lycopene dapat menurunkan kolesterol karena mencegah nitogen dioksidase menginduksi oksidasi membran lipid dengan cara berikatan dengan membran sel dan berinterkasi dengan komponen lipid (Rao \& Agarwal, 2000), mereduksi stress oksidatif, dan perusakan subsekuen lipoprotein plasma (Bohm et al., 1995; Basu \& Imran, 2007).
Tabel 4. Hasil Perhitungan Beda Nyata Terkecil

\begin{tabular}{ccc}
\hline Perlakuan & $\begin{array}{c}\text { Rata-Rata Kolesterol } \\
\text { Darah }(\mathbf{m g} / \mathbf{d l})\end{array}$ & Notasi \\
\hline $\mathrm{P}_{0}$ & 160,6 & $\mathrm{a}$ \\
$\mathrm{P}_{1}$ & 145,8 & $\mathrm{ab}$ \\
$\mathrm{P}_{2}$ & 138,6 & $\mathrm{ab}$ \\
$\mathrm{P}_{3}$ & 121,3 & $\mathrm{~b}$ \\
\hline
\end{tabular}

Sumber: Hasil Penelitian (2015)

Hasil perhitungan juga menunjukkan bahwa hanya perlakuan 3 yang memberikan perbedaan dengan kelas kontrol. Hal ini mungkin terjadi karena tidak diperhitungkannya lama penyimpanan tomat, jenis varietas tomat yang digunakan dan juga tidak diadakan pengukuran kandungan dari pasta tomat yang diberikan kepada mencit. Selain itu, faktor eksternal mungkin berpengaruh pada kolesterol darah mencit karena mencit hanya ditempatkan secara kelompok dan tidak secara individu.

Hasil penelitian juga menunjukkan berat badan mencit tidak terpengaruh oleh kandungan kolesterol darahnya. Pada mencit yang kolesterol darahnnya lebih rendah memiliki massa tubuh yang lebih besar, hal ini menunjukkan bahwa massa tubuh tidak berhubungan dengan kolesterol darah.

\section{Simpulan}

1. Terdapat pengaruh pasta tomat terhadap kolesterol darah mencit yaitu menurunkan kolesterol darah mencit secara signifikan.

2. Perlakuan $\mathrm{P}_{3}$ merupakan perlakuan yang memberikan hasil berbeda secara signifikan terhadap kelas kontrol sehingga $\mathrm{P}_{3}$ merupakan perlakuan terbaik untuk menurunkan kolesterol darah mencit.

\section{Daftar Pustaka}

Agarwal, S \& Rao, AV. 2000. Tomato lycopene and its role in human health and chronic diseases, CMAJ, 163(6): 739-744.

Alda, L,M. Gogoasa, I. Despina-M, B. Gergen, I. Alda, S. Calemia, M. \& Nita, L. 2009. Lycopene content of tomatoes and tomato products, Journal of Agroalimentary Processes and Technologies, 15(4): 540-542.

Bantas, K. Farida, MTA. Dinie, Z. 2012. Risiko Hiperkolesterolemia pada Pekerja di Kawasan 
Industri. Jurnal Kesehatan Masyarakat Nasional, 6(5): 219-224

Basu, A \& Imran, V. 2007. Tomatoes Versus Lycopene in Oxidative Stress and Carcinogenesis, Eur J Clin Nutr, 61(3): 295-303.

Betteng, R. Damayanti, P \& Nelly, M. 2014. Analisis Faktor Resiko Penyebab Terjadinya Diabetes Melitus Tipe 2 Pada Wanita Usia Produktif Di puskesmas Wawonasa. Jurnal e-Biomedik (eBM), 2(2): 404-412.

Bohm F. Trinkler JH. Truscott TG. Carotenoids protect against cell membrane damage by the nitrogen dioxide radical. Nat Med. 1995: 1:98-99.

Davies. 2000. Tomatoes and Health. Journal of Social Health, 120(2): 81-85.

Di Mascio P. Kaiser S. Sies H. Lycopene As The Most Efficient Biological Carotenoid Singlet Oxygen Quencher, Arch Biochem Biophys, 274:532 - 538.

Inzucchi, S. Porte, D. Sherwin, R. \& Baron, A. 2005. The Diabetes Mellitus Manual : A Primary Care Companion. Edisi 1. New York: Mc Graw-Hill Companies.

Jelantik, I.G.M.G. 2014. Hubungan Faktor Risiko Umur, Jenis Kelamin, Kegemukan Dan Hipertensi Dengan Kejadian Diabetes Mellitus Tipe Ii Di Wilayah Kerja Puskesmas Mataram. Media Bina Ilmiah, 8(1): 39-44.

Jenkins, J.A \& G. Mackinney. 1955. Carotenoid of the Apricot Tomato and Its Hybrids with Yellow and Tangerine, Online (http://europepmc.org/backend/ptpmcrender. fcgi?accid=PMC1209752\&blobtype=pdf), diakses 25 Oktober 2016.

Kelkel, M. Marc, S. Mario, D. \& Marc, D. 2011. Antioxidant and anti-proliferative properties of lycopene, Free Radical Research, 45(8): 925-940.

Kemenkes RI. 2012. Buletin Jendela Data dan Informasi Kesehatan Penyakit Tidak Menular, Jakarta; Kemenkes RI

LIPI. 2009. Kolesterol Tinggi. Balai Informasi Teknologi LIPI, Jakarta; LIPI

Miller NJ. Sampson J. Candeias LP. Bramley PM. Rice-Evans CA. Antioxidant activities of carotenes and xanthophylls. FEBS Lett 1996; 384:240 - 242.

Nasir, M, U. Sarfaz, H. \& Saqib, J. 2015. Tomato processing, lycopene and health benefits: A review, 3(1): 1-5

Shi, J. and M. LeMaguer. 2000. Lycopene in Tomatoes: Chemical and Physical Properties Affected by Food Processing. Critical Review of Food Science and Nutrition, 40(1) : 1-42.

Stancu, C. \& Anca, S. 2001. Statins: Mechanism of Action and Effects, Journal of Cellular and Molecular Medicine, 5(4): 378-387

Sullivan, S, O. 2007. Statins: A review of benefits and risks. TSMJ, 8: 52- 56.

Thompson, K. A., M. R. Marshall, C. A. Sims, C. I.Wei, S. A. Sargent, J. W. Scott. 2000. Cultivar,Maturity, and Heat Treatment on Lycopene Content in Tomatoes. Journal of Food Science, 65(5): 791-795.

Williams, H. 2005. Dislipidemia-Terapi Obat, Hosppharm, Online (https://lyrawati.files. wordpress.com/2008/07/dislipidemia_obat_hosppharm1.pdf), diakses pada 25 Oktober 2016 